\title{
"I ONLY KNOW ONE ME". TERRY TEMPEST WILLIAMS’ ECO-WRITING FROM A MORMON PERSPECTIVE
}

\author{
Ángel Chaparro Sainz \\ EHU/Universidad del País Vasco
}

\section{Abstract}

Terry Tempest Williams was raised in a family whose roots go deep into the history of the Church of Jesus Christ of Latter-day Saints, better known as the Mormon Church. In her writing, Williams negotiates her own identity. In that negotiation, both Nature and faith play important roles to understand her engagement into the art of writing and her own definition of self. Williams is able to articulate a personal but significant dialogue with Nature, one in which Nature speaks to her in pregnant ways. That intimate conversation is also fundamental to understand her reflections on faith. Eventually, her contemplation of her relationship with the Divine operates also as a useful system of enlightenment and discovery to fathom her connection to the natural space. Thus, she seems to establish a bond between the spiritual and the material that is visible in how she defines herself through words which are also selected and braided by way of a sophisticated style combining ethereal and corporeal angles.

Keywords: Terry Tempest Williams, Mormon faith, Negotiation with Nature, Eco-Writing.

"HAY SOLO UN YO QUE CONOZCA": LA ECO-ESCRITURA

DE TERRY TEMPEST WILLIAMS DESDE UNA PERSPECTIVA MORMONA

\section{RESUMEN}

Tery Tempest Williams creció en una familia enraízada firmemente en la historia de la Iglesia de Jesucristo de los Santos de los Últimos Días, más conocida como la Iglesia Mormona. En sus escritos, Williams negocia con su propia identidad. En dicha negociación tanto la naturaleza como la fe juegan un papel importante para comprender su implicación en el arte de escribir y su propia definición como persona. Williams es capaz de articular un diálogo personal, pero significativo, con la naturaleza, en el que la naturaleza le habla de forma reveladora. Una conversación íntima que es fundamental para comprender sus reflexiones sobre la fe. Incluso, la contemplación de su relación con lo divino opera además como un sistema útil de iluminación y descubrimiento que desentrańa su conexión con el espacio natural. Así, parece establecer un vínculo entre lo espiritual y lo material, que es visible en la forma en que se define a sí misma a través de palabras selectas y entrelazadas por un estilo sofisticado que combina ángulos etéreos y corpóreos a un tiempo.

Palabras clave: Terry Tempest Williams, fe mormona, negociación con la naturaleza, eco-escritura. 
In A Voice in the Wilderness: Conversations with Terry Tempest Williams, Michael Austin selects a representative sequence of interviews, talks and conversations that Terry Tempest Williams granted from 1989 to 2005. In those conversations, Williams, whose books have been approached and analyzed from very different perspectives, unveils the complex nature of her literature. Her frank but composite recognition of the many ingredients that shape her literature unconsciously evidences the value of her contribution.

Williams was born in 1955 in Corona, California. However, she was raised in Salt Lake City, Utah. She presently lives very close to Moab. Her life has been defined by change and movement. She has been a teacher in Montezuma Creek, Utah, in a Navajo Reservation; curator of education and naturalist-in-residence at the Utah Museum of Natural History; conservationist; an activist; and, obviously, she is a writer and a poet. As a writer, her production has always been related to landscape, place, ecology, wilderness preservation and women's health. In a way, those themes do come as no surprise to anybody. They can be hinted in her biographical account. Her vital journey, both when focusing on the land and the road, or on the task and the job, left fingerprints in her literature.

In any case, to make a thorough examination of her biography would mean a long and fatal detour from the goal of this study. The same could be said if I now try to review her entire literary record. Since, in 1984, she collaborated with Ted Major in the edition of the book for children The Secret Language of Snow, her books have achieved international recognition. Refuge: An Unnatural History of Family and Place, published in 1991, was the first, and probably still, the biggest success that she has enjoyed; Desert Quartet: An Erotic Landscape, in 1995, relied on the addition of Mary Frank's art; New Genesis: A Mormon Reader on Land and Community, in 1998, was another exercise on edition, this time, working side by side with William B. Smart and Gibbs M. Smith; Leap was published in 2000 and it seems to be the retelling of a research on Hieronymus Bosch when, in fact, it is a much more intricate insight into the author's faith; finally, Red: Passion and Patience in the Desert, published in 2001, took her back to a familiar landscape that she abandoned in the previous book.

Other scholars would highlight other works. The list is crippled and whimsical. But, still, these works are representative; they explain why, in the almost thirty years that Williams has spent writing, she has been awarded and distinguished with many different honors and recognitions. As with her books, the following list is just a little sample: the Utah Book Award (2000), the Utah Governor's Award in The Humanities (1995), Robert Marshall Award from the Wilderness Society (2006), the Wallace Stegner Award for the Center for the American West (2005), the Distinguished Achievement Award from the Western American Literature Association (2006) or the John Wesley Powell Award, The Grand Canyon Trust in 2008. Or, just to mention one more, the AML Award for Personal Essay in 1991 and in 1995.

AML is the acronym for the Association for Mormon Letters. In 1991, she earned this distinction for Refuge: An Unnatural History of Family and Place. The same year in which Laurel Thatcher Ulrich won, in another category, biography this time, with A Midwife's Tale: The Life of Martha Ballard Based on Her Diary 1785- 
1812, also a winner of the Pulitzer Prize. Four years later, in 1995, Williams won again, and in the same category, with Desert Quartet. Curiously, it was the same year that Michael Austin, editor of Voice in the Wilderness, won the AML award to the best piece of criticism with "How to Be a Mormo-American; Or, The Function of Mormon Criticism at the Present Time."

It is not an unimportant coincidence that Austin's and Williams' honors happened at the same time.At least, in the context of this study, the accident is relevant. Terry Tempest Williams, as she herself has stated, was raised within the cultural tradition of the Church of Jesus-Christ of Latter-day Saints: "I grew up in a Mormon household where that was the focus of our lives. It was the fabric that held everything together" (Austin 155). In her books, she shows that her engagement to the Church has been complex and unstable. Presently, her distance from the Church is probably bigger than ever. In a recent interview to Laura Flanders for The Nation she confessed that "I'm certainly not orthodox, and I don't practice the religion, but I do practice some of the ideals I was raised with" (Flanders 1). In any case, her spiritual path -and the traditions, ideals and tenets of a religious community into which she was born- plays an important role that becomes noticeable in her books. The way in which she delivers her spiritual dimension and the way in which she merges it with those other meaningful aspects of her life (place, activism or motherhood) conjure the personal philosophy and the intimate spirit that characterizes her writing. This combination offers not only a different approach to the landscape of the American West but also an enriching and sophisticated way into Mormonism, both as a religion and as a community. Michael Austin's article grants a wider critical context to this specific reading of Williams' literature. In "How to Be a Mormo-American", Austin claims for a place for Mormon literature within the studies of Western American literature; and, at the same time, he is also claiming for a much more open and wide notion of what Mormon literature is and can be. There, Williams becomes a promising certainty for Austin's desires. Whether when thinking about complicating the definition of Mormon Literature, or when integrating different perspectives to Western American literature, Terry Tempest Williams' literary proposition turns out to be a pregnant and poignant contribution.

The quotation on the title of this article springs from the answer that Terry Tempest Williams herself gave when inquired about her many facets as wife, naturalist, activist, writer, speaker, educator, scientist and environmentalist. The interview can be found in the already mentioned book by Michael Austin. Williams unveils how her concept of self relies on a complex combination of many different elements. In fact, Williams takes advantage of her writing to negotiate her own identity; in that negotiation, both nature and faith play important roles to understand her engagement in the art of writing, and her definition of self.

Williams was raised in a family whose roots go deep into the history of the Church of Jesus Christ of Latter-day Saints, better known as the Mormon Church. Her Mormonism plays an important role to understand her connection to nature and her commitment to activism and writing, but nature is also fundamental to understand how Williams compromises her membership to the Mormon Church and even her most intimate impulse for spiritual experience. Eventually, her con- 
templation of her relationship with the Divine operates also as a useful system of enlightenment and discovery to fathom her connection to the natural space. Thus, she seems to establish a bond between the spiritual and the material that is visible in how she defines herself through words which are also selected and braided by way of a sophisticated style combining ethereal and corporeal angles.

Williams confesses that she is aware of how her Mormon upbriging plays a role both in her life and in her writing: "So I'm aware of my biases, which are gender, geography, and culture. I am a Mormon woman writing out of the Great Basin, the Colorado Plateau" (Austin 68). In another interview, she uses a different term; not bias, but lenses: "Mormonism is one of the lenses I see the world through. We cannot escape our conditioning. Why would we want to? I grew up in a Mormon household where that was the focus of our lives. It was the fabric that held everything together" (Austin 155). Whether you call it bias or lenses, Williams talks about the influence and consequences of that upbringing and of her spiritual thirst.

Another Mormon writer with whom Williams shares many qualities, Phyllis Barber, agrees with her when she underlines the same idea as she reflects on her personal life, on and off the Mormon Church, and her need to record that experience through her writing: "You suspect if you want to write something that matters, you need to examine the biases in your characters which can be understood only after reflecting upon the biases in your own character" (Barber xv).

Barber highlights the need to explore those biases through fiction. Her understanding of identity as a matter of biases allows for contradiction, complexity and conflict. It is a definition that allows her to portray good and evil in the wide array of degrees that this complex dichotomy triggers. The same pattern can be found in Terry Tempest Williams. Bias or lenses, both imply coming from the inner room to the outter world. They do not talk about a set of rules being imposed from the outside, but about a set of beliefs and cultural values that they have adopted or inherited and that, somehow, have shaped their perception of the world.

In this article, I aim at exploring the role that faith plays in Terry Tempest Williams' literary production. Mormonism affected her commitment with environmental writing and activism in different ways and that is what I aim at explaining here. In most cases, when analyzing her books, Mormonism has been put aside, or it has just been mentioned as a secondary element. It is my impression that the treatment of faith in her literature proves to be a key element to understand what she says and how she says it.

If we go back to the few books that I chose to give a sample of Williams' literary production, it becomes obvious why I chose them and not others. In fact, I will be mainly quoting here three books: Refuge: An Unnatural History of Family and Place, Red: Passion and Patience in Desert and Leap. In the three of them -even though references to her faith can be found in other books-Mormonism is a constant presence. Refuge turns out to be a complex and personal approximation to a very specific event: the year the rising of the Great Salt Lake was close to finish with the Bear River Migratory Bird Refuge. Again, Williams establishes strong connections between nature, family and place. Her literary confession intertwines her past with the present time: cancer, the fallout of atomic bombs, her Mormon upbringing, 
birds... All of these aspects act as symbolic and real elements to organize her most intímate definition. Red is a collection of essays, stories and testimonies on different topics, specially focusing on the preservation of wildness and the desert. In any case, this fight for preservation is more spiritual than political. Mormonism and the concept of family are also a part of this confession of feelings towards the arid landscape. Finally, Leap become a very important book to understand Williams' spiritual engagement -"a book of questions," she says (Austin 120). The book describes her falling in love with a painting. It tells the story of her trip to Madrid to study Hieronymous Bosch's The Garden of Earthly Delights, but it becomes a return to her connections to the Earth and her religion.

To examine how faith, and specifically Mormonism, influences Terry Tempest Williams' literary cosmos I fancy a practical classification that divides her touch on faith in two different categories. First, what I call a positive one, a category in which I garner all the assertive and nourishing constituents from the Restored Gospel or the Mormon community and culture that Williams praises and seizes in her writing. Second, a negative one, again, a category in which to gather all the features in Mormonism that Williams rejects, criticizes or penalizes. There would be a potential third category: a combination of these first two; when the negative and the positive aspects combine to create a paradoxical one in which lies the most important contribution of her spiritual dimension to act on her personal formation of a sense of self.

There are many cultural and spiritual ingredients inherited from her Mormon upbringing that Williams sanctions and celebrates. For instance, in her books, there are many references to the legacy of Brigham Young, and all of them are positive and approving. Williams highlights the stress on land ethics promoted by this Mormon leader. In any case, when Williams underlines the heritage of Brigham Young, she is just condensing Mormon ethics towards the land in the figure of a man.

Joseph Smith, prophet and founder of the Mormon Church, was mayor of Nauvoo at the time when this city was becoming one of the most prosperous cities in the midwest -first successful attempt to build the kingdom of Zion on earth (Mormons believe that this is their mission on earth). However, the death of the main leader became a breaking event that triggered subsequent attacks against the Mormons, giving an end to this merry period. It all started when Joseph Smith decided to close the Nauvoo Expositor, a periodical being published for the first time. William Law and Robert Forster were actually excommunicated due to their opposition to Smith. The Nauvoo Expositor intended to express critical opinions regarding the new doctrines that Smith had put into practice in Nauvoo. Smith decided to close the newspaper. The tension increased dangerously and, finally, Smith was put in jail in Carthage. While in there, Smith was killed by a mob. His death brought the founding period of the Church to an end. The Mormons were forced to move again and the exodus to the West began.

Brigham Young took the leadership of the Church after Joseph Smith's death. Young was convinced to implement all the visions that Smith had. Under his command, Mormons started their role in the pioneering of the American West, an episode that would turn out to be a fundamental experience to make 
the community stronger and tighter. In Mormon history, Young appears as the second main important figure: the man who tried to accomplish what Smith had envisioned before him.

Terry Tempest Williams relates her portrayal of Brigham Young as a positive memory. She underlines the patrimony that Young's commitment and philosophy left as a valuable heritage; his success in winning a proper place for a new community in a land that he learnt to love:

In Utah, there was a man with a vision. He dreamed of a civilization bright with lights and strong of belief. He knew the industrious nature of work and picked the beehive as his symbol. He loved the land he saw before him, a landscape so vast, pristine, and virginal, that he recognized it as the kingdom of God, a place for saints with a desire for home. The desert country of the Great Basin and Colorado Plateau was an answer to prayers of spiritual sovereignty.

He sent families north into the mountains and south into the valleys where redrock walls rose upward like praying hands. He said: "We will create Zion among the wilderness." And with great stamina and imagination akin only to communities committed to faith, the building of culture among the pioneers began. Humble ranches, small businesses, and cottage industries of silk and wool sprung up and a United order was dreamed. (Williams, Red 74)

Williams' account illustrates Young's love of the land, but it also testifies to Williams' own love for this landscape. Nevertheless, her definition of Young as "the colonizing prophet" (Williams, Red 74) works as a proper label to understand the impact that the strategies launched by Young had, not only for the Church, but also in the history of the American West. This is the main reason for Williams' respect: the land ethics that Young promoted. Edward A. Geary, another Mormon writer, poses the same portray in his personal account of Young in Goodbye to Poplarhaven: Recollections of a Utah Boyhood. Geary not only introduces Young's stress on communal work, he also emphasizes Young's entrepreneurism and ideology for Mormon success in the attempt to establish a fortunate community in the West:

That, in a nutshell, was Brigham Young's philosophy of community building: the faith in the power of work, the fearlessness of risk, the confidence of success. It was not merely a theoretical program, but one tested repeatedly over the thirty years that he directed Mormon colonization in the West. Some colonies failed, and the tumbleweed blows today across abandoned fields. But most of the fourhundred-odd towns and villages that Brigham Young planted grew and flourished, at least up to a point. If the inhabitants didn't exactly get rich in ten years, they did have comfortable homes, orchards, flocks, herds, and a community that worked. (Geary, Goodbye 9)

Williams expands on this topic in an interview: "If you go back and look at the teachings of Brigham Young, his journals and sermons, they are filled with very strong notions of sustainability. Early brethren of the Mormon Church gave rousing speeches on the perils of overgrazing and the misappropriation of water in the desert" (Austin 95). Williams underlines also how Young and some other leaders 
in the Mormon Church -Lorenzo Snow- tried, in those days, to launch communal and socialistic projects -the United Order (Refuge 99-103)- in settlements such as Brigham City: "He loved the land he saw before him, a landscape so vast, pristine, and virginal, that he recognized it as the kingdom of God, a place for saints with a desire for home" (Williams, Red 74).

Home. That word resounds with additional meaning. Some other important aspects of Mormonism, presented in a friendly and profitable manner, and visible in Williams' writing, are those related to family, tradition, heritage, history and how this is related to and framed by a very specific land to which she belongs and by a faith that shaped her. Those concepts provide a sense of certainty that she perceives as a source of security and shelter, a source of meaning and reliability that, as I will show later, can also be the cause of conflict and denial.

Howard W. Hunter, fourteen president of The Church of Jesus Christ of Latter-day Saints, states that family is "the most important unit in time and in eternity" (51). Boyd K. Packer, president of the Quorum of the Twelve Apostles, writes that "the family is safe within the Church" (22). Wallace Stegner states that "the family is so important in Mormon religion that without it, the religion would hardly exist" (112). Precisely, James Alexander Trombley says about the concept of family when analyzing Wallace Stegner's perception of the Mormons that "Among the Mormons, the supreme virtues of family, community solidarity, history and tradition would contribute significantly to the elaboration of Stegner's concept of the sense of place" (Trombley 31). And Claudia L. Bushman confirms this notion when she states that, in Mormon Church, "the basic unit [is] the family rather than the individual" (176). Family, in Mormonism, is a basic ingredient, both socially and spiritually.

In Refuge, she exemplifies the importance of community and history with a certain level of pride when she talks about her long tradition in the land she loves: "Almost one hundred and fifty years later, we are still here" (Williams, Refuge 13). History, tradition and family trees are a very important part in her life: "Genealogy is our blood. As a people and as a family, we have a sense of history. And our history is tied to land" (Williams, Refuge 14). As I said before, when looking backwards, she perceives this certainty as a positive attribute: "And with great stamina and imagination akin only to communities committed to faith, the building of culture among pioneers began. Humble ranches, small businesses, and cottage industries of silk and wool sprung up and a United Order was dreamed" (Williams, Red 74). In the present time, that connection seems to be driven from the land rather than any other source of connection: "The sweet smell of sage as fuel for our spirits" (Williams, Refuge 290). In any case, family and her sense of engagement to the land do also spring with conflicting consequences: "It is comforting and disturbing, at once" (Williams, Refuge 14). Her father is a pipeline contractor and his interest in the land clashes with her daughter's activism in favor of the protection of the desert. Still, she does not reject this heritage - "We are a family of pipelines contractors" (Williams, Red 72) - and she values it as part of her powerful association to the landscape.

That sense of community and of social unity is also present in her compulsion to feel connected to other women who had suffered breast cancer in Refuge. 
Her Clan of One-Breasted Women resounds with echoes that evoke the communal collaboration between women in Mormon society. In Leap, she confesses how the land is also part of her family history: "These mountains in time were hollowed to house the genealogy of my people, Mormons" (Williams, Leap 5). She confesses that she finds cherish in how the concept of family is a founding tenet of Mormon religion. However, Williams amplifies that communal feeling: "Would you believe me when I tell you this is family, kinship with the desert, the breadth of my relations coursing through a wider community, the sock of recognition with each scarlet gilia, the smell of rain" (Red 157). She celebrates that land and people are connected, bond together. Her sense of community binds them together: "Our attachment to the land was our attachment to each other" (Williams, Refuge 15).

In any case, a negative veneer does also cover these layers of her writing. Mormonism in Williams' literature does also denote a discourse of authority, conformity and patriarchy. Compulsory motherhood would be another negative element: "I despise the lack of thinking inherent to all orthodoxies, where humanity's responsibility to the here-and-now is abdicated to a blind faith in 'the life hereafter" (Austin 18). Williams is sharp and energetic in confessing her uneaseness with certain attributes that seem to be implicit in her understanding of religion: "Tolerating blind obedience in the name of patriotism or religion ultimately takes our lives" (Refuge 290).

A descriptive metaphor of her disenchantment with the Mormon Church is the lyrical tension between the burden of truth and the attraction to mystery. Obviously, religion is a source of certainty, but that certainty can be also a limiting drive: "Religions being as a salve to mystery, not a manifesto to truth. We too can interpret the truth and make it our own" (Williams, Leap 88). Williams guards her right to question and explore as an important ingredient of her life, even when considering her faith: "As a Mormon woman of the fifth generation of Latter-day Saints, I must question everything" (Refuge 286). And this seems to clash with how she was raised within her religion: "While growing up, how many times, I thought to myself, had we heard that Mormon phrase: 'This is the only true Church?' Something inside of me, very early on, just kept saying no" (Austin 102). Williams states that "in Mormon culture, authority is respected, obedience is revered, and independent thinking is not" (Refuge 285); nevertheless, she concludes that she feels the need "to question everything, even if it means losing my faith, even if it means becoming a member of a border tribe among my own people" (Williams, Refuge 286).

Her resistance to accept pre-conceived notions, her reluctance to bend to cultural roles, and her non-conformist spirit interfere with one of the most conflictive aspects in Mormonism: that of motherhood. Mormon orthodoxy proposes a classification of roles that give women the responsability of mothering, while men are expected to engage in the Church system and exercise their careers in priesthood. It must be considered that, when talking about gender roles in Mormonism, these roles are part of membership -part of the engagement of the members to the Church. For women, the Church suggests that motherhood and wifehood are the appropriate roles: 
Successful marriages and families are established and maintained on principles of faith, prayer, repentance, forgiveness, respect, love, compassion, work, and wholesome recreational activities. By divine design, fathers are to preside over their families in love and righteousness and are responsible to provide the necessities of life and protection for their families. Mothers are primarily responsible for the nurture of their children ${ }^{1}$.

Red probably contains some of her most straightforward statements against this determined path that Mormon women seem to received as a given: "it is our freedom to choose how we wish to live, labor, and sacrifice in the name of love" (Red 163). When she talks about Mary Austin, she cries that "too many women have been silenced in the name of 'niceness"' (Williams, Red 166). In short, Williams expresses her natural rejection of any imposition while she embraces the moral responsibility to exercise choice.

Faith is a cardinal component in Terry Tempest Williams' eco-writing, but also a powerful medium to unveil her personal construction of her intimate self. Williams herself reflects on the relevance that Mormonism has in her books: "Leap is a book that certainly has a Mormon reader in mind, and Refuge has different reference points for Mormon readers as well, but I would hope that there's universality to the stories that transcends the Mormon community" (Austin 182). That universality that she craves for resides in the concept of paradox. Paradox is a very important element in her writing and it is very helpful to understand her commitment to faith: "This is the paradoxical ability that we have to hold opposing views in our mind at once, in our heart at once" (Austin 25). Paradox is a useful manner to handle her impulse to negotiate opposing extremes. Michael Austin explains that Williams would love to see "the whole notion of opposition dissolved" (40). In fact, Williams herself praises that when she talks about Wallace Stegner: "He understood that part of the tension of being human is found in our desire for, and love affair with, both risk and security" (Williams, Introduction xv). Williams, rather than accepting any drastic position, adopts the paradox: "[P] aradox is life. It's the same thing as balance. You can't have one without the other. There's always the creative third, which is where possibility lies" (Austin 44). That paradoxical middle positioning has a reflection in her literature. Her language exhibits that position by rhyming spiritual resistance, holiness and testament with physical elements such as sand, bones, rivers; the soul and the body: "deserts turn us into believers" (Williams, Red 77). She ventures to reconcile the spiritual values of Mormonism that she enjoys with the trascendence of the bodily experience of the landscape. She says: "Free agency. I saw the process of natural selection as an act of biotic faith, an organic definition, an extension, of what I understood the concept of eternal progression to be in Mormon theology, that

${ }^{1}$ President Gordon B. Hinckley read this procclamation for the first time as part of his message to the General Relief Society Meeting held in Salt Lake City, Utah in 1995. The present quotation has been taken from the text published by The Church of Jesus Christ of Latter-day Saints in their official website. 
of advanced perfectionism" (Williams, Leap 35). But, at the same time, she defends that "What we know in a wild place is largely translated through the body" (Williams, Red 186). In her own words, and even if paradoxical (or probably, thanks to it), the spiritual and the material, with the specific characteristics of her Mormon education, seem to define how Williams understands her significant connection to the land in which she dwells: "Spiritual beliefs are not something alien from Earth, but rise out of its very soil. Perhaps our first gesture of humility and gratitude were extended to Earth through prayer, the recognition that we exist by the grace of something beyond ourselves" (Williams, Leap 88-89).

Terry Tempest Williams exemplifies the complexity and quality that Mormon literature enjoys today. Williams, naturalist, professor and writer, is one of the most powerful voices in Western American literature dealing with environmentalism. In fact, her books, a hybrid association of memory, poetry, science and political commitment, go beyond any label. In many of her books, Williams has talked openly and earnestly about her identity which, in her own words, is formed by her own biases, "which are gender, geography, and culture" (Austin 68). Also faith, as I have tried to explain in this article. Michael Austin points out that "Mormon readers often express frustration with her unorthodoxy and her criticisms of the faith's emphasis on conformity, authority, and patriarchy" (7). The secret always lies in the middle of the road. Faith is an important element to discover the complex architecture that underpins Williams' understanding of her commitment to nature, but it also contributes to the improvement and prosperity of Mormon literature, and by extension, that of Western American literature and eco-writing.

Reviews sent to author: 11 March 2018 Revised paper accepted for publication: 2 July 2018 


\section{WORKS CITED}

Austin, Michael: A Voice in the Wilderness: Conversations with Terry Tempest Williams. Logan: Utah State University Press, 2006. Print.

Austin, Michael: "How to Be a Mormo-American; Or, the Function of Mormon Literary Criticism at the Present Time." Mormon Literature Website. Brigham Young University, Oct. 2010. Web. 3 Oct. 2010.

Barber: "Writing: An Act of Responsibility." The Best of Mormonism. Ed. Stephen Carter. Salt Lake City: Curelom Books, 2009. xiii-xxi. Print.

Bushman, Claudia L.: "Should Mormon Women Speak Out?: Thoughts on Our Place in the World." Dialogue: A Journal of Mormon Thought 41 (1) March 2008: 170-184. Dialogue: A Journal of Mormon Thought. Web. 3 Oct. 2010.

Flandes, Laura: “Tempest Williams: The Mormon Church Is Corporation.” Laura Flanders Blog. The Nation. Web. 3 Oct. 2010.

Geary, Edward A.: Goodbye to Popolarhaven: Recollections of a Utah Boyhood. Salt Lake City: University of Utah Press, 1985. Print.

Hunter, Howard W.: “Being a Righteous Husband and Father.” Ensign 24 November 1994: 49-52. Ensign. Web. 3 Oct. 2010.

Packer, Boyd K.: “The Father and the Family.” Ensign 24 May 1994: 19-22. Ensign. Web. 3 Oct. 2010.

Stegner, Wallace: Interview. Stegner: Conversations on History and Literature. By Richard Etulain. Reno: University of Nevada Press, 1998. Print.

Trombley, James Alexander: "A Simultaneous and Joined Identity: The Ecocommunitarian Ideal in Wallace Stegner's American West.” Cercles 13 (2005): 25-43. Print.

Williams, Terry Tempest, Smart, William B. and Smith, Gibbs M.: New Genesis: A Mormon Reader on Land and Community. Salt Lake City: Gibbs Smith Publisher, 1998. Print.

Williams, Terry Tempest: Introduction. Crossing to Safety. By Wallace Stegner. New York: The Modern Library, 2002. Print.

Williams, Terry Tempest: Leap. New York: Pantheon Books, 2000. Print.

Williams, Terry Tempest: Red: Passion and Patience in the Desert. New York: Vintage Books, 2001. Print.

Williams, Terry Tempest: Refuge: An Unnatural History of Family and Place. New York: Vintage Books, 1992. Print. 
